\title{
The Priority of Exploiting Fiscal Revenue or Lessening Public Expenditure: Evidence from China
}

\author{
Yu kun Wang ${ }^{1}$, Li Zhang ${ }^{1}$, We-me Ho ${ }^{1}$ \\ ${ }^{1}$ Department of Economics and Finance, Guangdong Ocean University Cunjin College, Guangdong Province, China \\ Correspondence: Yu Kun Wang, Department of Economics and Finance, Guangdong Ocean University Cunjin College, \\ No. 1, Haida Road, Mazhang District, Zhanjiang City, Guangdong Province, China.
}

Received: December 3, 2019

Accepted: February 18, 2020

Available online: February 24, 2020

doi:10.11114/afa.v6i1.4731

URL: https://doi.org/10.11114/afa.v6i1.4731

\begin{abstract}
In the past 28 years, we find that except for the fiscal revenue of 5,132.1 billion yuan in 2007, which is greater than the fiscal expenditure of 4,978.1 billion yuan, presenting a fiscal surplus, the fiscal expenditure of the rest years is greater than the fiscal revenue, showing the situation of public sector net cash requirement (psncr), especially in 2011, the deficit( the gap between fiscal expenditure and fiscal revenue) is 537.3 billion yuan. Since then, the gap between expenditure and revenue has been increasing with each passing year. In 2015, the fiscal deficit is 2,368 billion yuan. In 2018, the fiscal deficit has been expanded to 3,754.4 billion yuan. In order to avoid the continuous increment of the deficit. This paper discusses the causal relationship between China's fiscal revenue and public expenditure from 1990 to 2018. If fiscal revenue has a positive impact on public expenditure, showing that the government shall reduce fiscal deficit through tax increment. On the contrary, it makes public expenditure continue to expand, leading to the continuous deterioration of fiscal deficit, so as to further decide whether China's future fiscal policy should adopt increasing fiscal revenue or deducting public expenditure policy to reduce the deficit.
\end{abstract}

Keywords: China, fiscal deficit, tax-spend hypothesis or spend-tax hypothesis

\section{Introduction}

In general, fiscal deficit of a government is caused by the fact that "the amount of revenue" is smaller than "the amount of expenditure". The causes of the deficit are quite complex. Theoretically, the solution is mainly to adopt "open source" or "flow saving". The traditional view of fiscal balance payment advocates static balance. It only considers the revenue and expenditure within one fiscal year. However, the view of fiscal dynamic balance discusses the influence of a country's economy in a specific period (cycle) on finance and the adjustment of finance to economic cycle. Because a country is a sustainable operation. To be correct, fiscal balance should not be limited to static balance, but should have a view of dynamic balance.For example, although major events of force majeure such as natural disasters occur in a certain year, the fiscal performance of that year is unbalanced, but if we observe from a cross annual range, the fiscal revenue and expenditure may still be balanced. Thinking about China is the second largest production and consumption economy in the world. This paper takes China as an example to discuss the increasing fiscal deficit in recent years and analyze the current fiscal deficit and tax base erosion with a rigorous empirical model.

\section{Literature}

Wagner (1976) considers taxation will affect expenditure, but shows a reverse relationship, Buchanan and Wagner (1977) and Niskanen (2006) also holds the same view that tax reduction will raise government expenditure, so tax increment is the correct method to alleviate fiscal deficit. Friedman (1978) figures out that tax will affect expenditure, but holds the opposite view. He believes that the impact of tax on expenditure is a positive relationship, the government tax increment will lead to more expenditure, so it is not suitable to reduce the deficit through tax increase. However, Barro (1979) argues that expenditure will affect tax revenue, which is a positive relationship. The increase of expenditure will lead to the increase of tax revenue. In addition, Peacock and Wiseman (1979) point out that special events will lead to the increment of public expenditure which will force the government to raise taxation, Hewitt(1986) and Winer(1983) show the separation of tax collection and consumption capacity is prone to fiscal illusion. Gramlich and Harvey (1973) propose the flypaper effect depicting the increment of the central government's fiscal subsidies to local governments is prone to be wasted by the local governments who receive the central government's subsidies.In 
this case, the finding was that a grant from federal government to local government would raise spending of that local government by a greater amount than an equivalent increase in local income. Meltzer and Richard (1981) support the financial synchronization hypothesis, holding that the size of government expenditure is not related to the fiscal illusion, arguing that government revenue will affect government expenditure, and government expenditure will also affect government revenue simultaneously, on the other hand, there exists a two-way causal relationship between revenue and expenditure at the same time. Cameron (1978) also holds the same view that the government must consider the scale of tax and expenditure under the precondition of balancing the budget.

In respect of relevant empirical literature, Pesaran and Shin (1999), Pesaran et al. (2001) and Christian Gross (2012) adopt the ARDL bound method to check whether there exist a co-integration relationship between variables.In addition, Obeng (2015) utilizes 1980-2013 raw data to explore the relationship between income and expenditure in Ghana, supporting the hypothesis that income will affect expenditure unidirectionally. Theoretically, regardless of whether the empirical result is "revenue influences expenditure" or "expenditure influences revenue", or whether there exists a "two-way effect", all do not violate the rigorous economic theory. In addition, "Simpson paradox" points out that under certain condition, when two groups of data are discussed separately, they meet certain characteristics, but when two groups of data are combined, they may result in the opposite conclusion. The major contribution of this paper is to determine the causal relationship between revenue and expenditure. At the same time, to determine whether the government finance should be open source or throttling. As mentioned earlier, if the revenue has a positive one-way impact on expenditure (tax spend hypothesis), it means that increasing fiscal revenue will lead to the increment of public expenditure, but reducing expenditure will not lead to the decrease of revenue. At this time, we shall take throttling policy as the main policy; however, if the expenditure has a positive impact on the revenue, it means that the decrease of expenditure will lead to the decrease of revenue, but the increase of revenue will not lead to the increase of expenditure. At this time, the government shall adopt the open source policy.

We review China's fiscal reform in 1994, China carried out "contract system" fiscal policy. Government tax revenue is divided into three categories: centralized control income, local control income, central and local shared income. At that time, the local government only pays a fixed amount of fiscal revenue to the central government. During that time, the China's central government has asked for a loan twice from the local government. The proportion of fiscal revenue to GDP and the proportion of central finance to overall fiscal revenue both declined rapidly. After the tax system reform in 1994, China has increased the proportion of fiscal centralization and reduced the proportion of local government's retained tax, and made the proportion of national fiscal revenue to GDP increment year after year. The proportion of national fiscal revenue to GDP increased from $10.72 \%$ in 1994 to $20.16 \%$ in 2010, 22.20\% in 2015 and above $20 \%$ later. On the other hand, the reform of tax distribution system in 1994 weakens the expansion effect of political cycle on local fiscal expenditure. At the same time of carrying out the reform of tax distribution system, the transfer payment system is established to alleviate the problem of financial disparity among regions (see Li Ruichang, 2012).

\section{Methodology}

This paper mainly focuses on the correlation between "the proportion of fiscal revenue to GDP" and "the proportion of public expenditure to GDP". We adopt empirical analysis to discuss the causal relationship between fiscal revenue and fiscal expenditure, in which fiscal revenue, public expenditure and GDP are measured in billion yuan.

The data of GDP, fiscal revenue and public expenditure in this paper are mainly derived from the National Bureau of Statistics of the People's Republic of China. Initially, the time series of fiscal revenue, public expenditure and GDP are logarithmic as shown in Figure 1, denoting that the time series of all three variables present an increasing trend, and those sequences show that the mean values are varying in different periods, we then judge that the sequences are non-stationary.

\subsection{Test of Serial Independence and Variance Ratio}

In this paper, the variables, LGDP, L(fiscalrevenue) and L(publicexpenditure) represent the logarithmic functions of GDP, fiscal revenue and public expenditure, respectively. Firstly, we adopt BDS independence test to check whether the time series variables are i.i.d. (see Brock (1996) et al.). Table 1 depicts the $\mathrm{p}$ values of L(fiscalrevenue/GDP) and $\mathrm{L}$ (publicexpenditure) are both 0.0000 , Hence, we reject the null hypothesis that the variables are i.i.d. Further, we use Variance ratio test to check whether the time series of variables exists a random walk process. Table 2 shows that variables L(fiscalrevenue/GDP) and L(publicexpenditure) in this model are not random walk process or "martingale".

However, Granger and Newbold (1974) propose false regression, Baumöhl et.al (2009) find that many original sequences exist non-stationary characteristics (see also Noriega and Ventosa-Santaularia,2006). Therefore, before conducting empirical research on time series analysis, it is essential to tackle with unit root problems as follow. (see also Dickey and Fuller,1979; Enders, 2010 ).

\subsection{Unit Root Test}


At first we propose to use the time duration from 1990 to 2018 as an analysis period to verify the existence of unit root. When we adopt ADF and PP unit root methods. As we know, the ADF unit root test does not consider whether the residual exists self correlation and heterogeneity. We add the PP test (Phillips and Perron,1988) which allows the residual items to have self correlation and heterogeneity variation.

Table 1. BDS independence test

\begin{tabular}{|c|c|c|c|c|}
\hline \multicolumn{5}{|c|}{ time period: from 1990 to 2018} \\
\hline \multicolumn{5}{|c|}{ I.BDS Test for LPUBLICEXPENDITUREWITHGDP } \\
\hline Dimension & BDS Statistic & $\underline{\text { Std Error }}$ & $\underline{\text { z-Statistic }}$ & Prob \\
\hline 2 & 0.154510 & 0.008997 & 17.17349 & 0.0000 \\
\hline 3 & 0.246857 & 0.014660 & 16.83860 & 0.0000 \\
\hline 4 & 0.300417 & 0.017901 & 16.78230 & 0.0000 \\
\hline 5 & 0.321433 & 0.019141 & 16.79316 & 0.0000 \\
\hline 6 & 0.343761 & 0.018949 & 18.14184 & 0.0000 \\
\hline \multicolumn{5}{|c|}{ II.BDS Test for LFISCALREVENUEWITHGDP } \\
\hline$\underline{\text { Dimension }}$ & $\underline{\text { BDS Statistic }}$ & $\underline{\text { Std Error }}$ & $\underline{\mathrm{z}-\text { Statistic }}$ & $\underline{\text { Prob }}$ \\
\hline 2 & 0.157722 & 0.009163 & 17.21359 & 0.0000 \\
\hline 3 & 0.256882 & 0.014833 & 17.31869 & 0.0000 \\
\hline 4 & 0.325812 & 0.017994 & 18.10718 & 0.0000 \\
\hline 5 & 0.365302 & 0.019115 & 19.11090 & 0.0000 \\
\hline 6 & 0.395069 & 0.018800 & 21.01425 & 0.0000 \\
\hline
\end{tabular}

Source: The original data source of Table 1 are derived from National Bureau of Statistics of the People's Republic of China and analyzed by us

Table 2. Variance ratio test

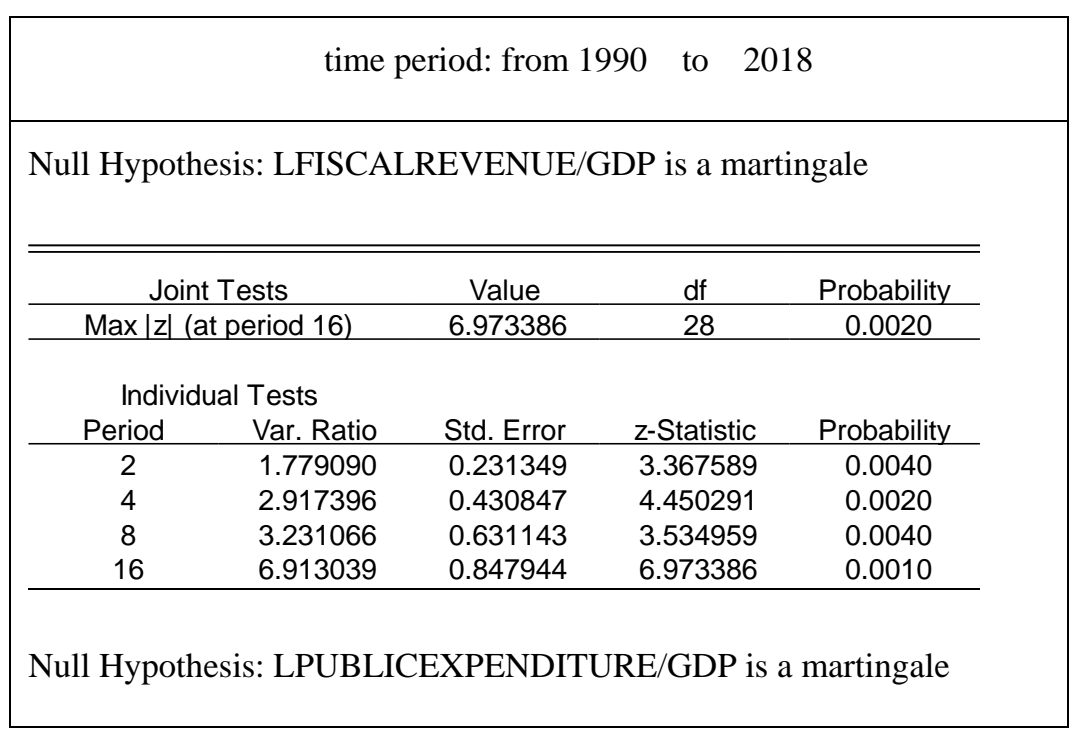




\begin{tabular}{|ccccc|}
\hline \hline \multicolumn{7}{c}{ Value } & df & Probability \\
\hline \multicolumn{6}{c}{ Joint Tests } & 4.012125 & 28 & 0.0110 \\
\hline \multicolumn{4}{c}{ Individual Tests } \\
\multicolumn{7}{c}{ Period } & Var. Ratio & Std. Error & z-Statistic & Probability \\
\hline 2 & 1.731379 & 0.230527 & 3.172647 & 0.0100 \\
4 & 2.629964 & 0.406260 & 4.012125 & 0.0050 \\
8 & 2.051714 & 0.591251 & 1.778796 & 0.0780 \\
16 & 4.020990 & 0.814696 & 3.708117 & 0.0050 \\
\hline \hline
\end{tabular}

Source: The original data source of Table 2 are derived from National Bureau of Statistics of the People's Republic of China and analyzed by us

The original data source in Table 1- Table 8 are derived from China Bureau of statistics, and analyzed by our paper through empirical analysis.

Except ADF and PP unit root test. KPSS unit root test provides a unit root test of another view. The results of unit root test are presented in Table 3, the"proportion of fiscal revenue to GDP in logarithmic form" appears stationary at the 2st-differenced form under $1 \%$ significant level, depicting the logged variables are I(2), and the "proportion of fiscal expenditure to GDP in logarithmic form" also appears stationary at the 2st-differenced form under $1 \%$ significant level, denoting the logged variables are also I(2). Furthermore, we use the KPSS unit root test, showing the "proportion of fiscal revenue to GDP in logarithmic form" and the "proportion of fiscal expenditure to GDP in logarithmic form" appear stationary at $\mathrm{I}(0)$ under $1 \%$ significant level, respectively. Since the order of the ADF and PP unit root test are $\mathrm{I}(2)$, whereas the order of KPSS unit root test is $\mathrm{I}(0)$. Thus, we can not proceed with Johansen co-integration test. (Johansen and Juselius,1990).

\subsection{Autoregressive Distributed Lag (ARDL) Test}

Nevertheless, Pesaran et al (2001) proposes the ARDL boundary test to solve the Problem of different order of variables, the advantage is the order of variables need not be considered in the co-integration process, that is to say, whether I $(0)$ of the stationary status or I(1) and I(2) unit root will not affect the testing results, and it can also clearly distinguish among these variables which are endogenous and which are independent. Clearly the boundary test proposed by Pesaran et al. (2001) is not restricted by the order of variables. It can clearly judge whether there exists a long-term equilibrium correlation and distinguish which is endogenous variable or independent variable. As we know there are five models for the boundary test in general. In this paper, the more general Case II model is adopted as follows.

$$
\begin{aligned}
\Delta \mathrm{L}(\text { fiscalrevenue/GDP })_{\mathrm{t}}=\alpha_{0} & +\pi_{\mathrm{L}(\text { fiscalre venue/GDP })^{2}} \mathrm{~L}(\text { fiscalrevenue/GDP })_{t-1} \\
& +\pi_{\mathrm{L}(\text { fiscalrevenue/GDPL(publicexpenditureGDP })^{2}} \mathrm{~L}(\text { publicexpenditure/GDP })_{t-1} \\
& +\sum_{i=1}^{p} \phi \Delta \mathrm{L}(\text { fiscalre venue/GDP })_{t-i}+\sum_{j=0}^{q} \gamma_{1 i} \Delta \mathrm{L}(\text { publicexpenditure/GDP })_{t-j} \\
& +\theta w_{t}+\mu_{t}
\end{aligned}
$$

Eq.(1) denotes that $\pi_{L(f i s c a l r e v e n u e / G D P)^{2}}$ and $\pi_{L(f i s c a l r e v e n u e / G D P) L(p u b l i c e p e n d i t u r e G D P)^{2}}$ are long-term parameters, $\theta w_{t}$ is a virtual vector of exogenous variables, the normal and deferred variables of $\Delta \mathrm{L}$ (fiscalrevenue/GDP) and $\Delta \mathrm{L}$ (publicexpenditure/GDP) are short-term dynamic structures. According to ARDL model, it is assumed that there are two variables in the economic system, and the long-term relationship between them can not be known from previous information. Thus, we initially list the following two equations, $\Delta \mathrm{L}$ (fiscalrevenue/GDP) and $\Delta \mathrm{L}$ (publicexpenditure/GDP), as dependent variables, respectively. 


$$
\begin{aligned}
\Delta \mathrm{L}(\text { fiscalrevenue/GDP })_{\mathrm{t}}= & \alpha_{1}+\sum_{i=1}^{p} \beta_{1 i} \Delta(\text { fiscalrevenue/GDP })_{t-i} \\
& +\sum_{j=0}^{q} \gamma_{1 j} \Delta \mathrm{L}(\text { publicexpenditure/GDP })_{t-j} \\
& +\theta_{1 L(\text { fiscalrevenue/GDP })} \mathrm{L}(\text { fiscalrevenue/GDP })_{t-1} \\
& +\theta_{2 L(\text { fiscalrevenue/GDP })} \mathrm{L}(\text { publicexpenditure/GDP })_{t-1}+\varepsilon_{1 t}
\end{aligned}
$$

$$
\begin{aligned}
\Delta \mathrm{L}(\text { publicexpenditure/GDP })_{\mathrm{t}} & =\alpha_{2}+\sum_{i=0}^{p} \beta_{2 i} \Delta \mathrm{L}(\text { fiscalrevenue/GDP })_{t-i} \\
& +\sum_{j=1}^{q} \gamma_{2 j} \Delta \mathrm{L}(\text { publicexpenditure/GDP })_{t-j} \\
& +\theta_{1 L(\text { publicexpenditure } G D P)} \mathrm{L}(\text { fiscalrevenue/GDP })_{t-1} \\
& +\theta_{2 L(\text { publicexpenditure/GDP })} \mathrm{L}(\text { publicexpenditure/GDP })_{t-1}+\varepsilon_{2 t}
\end{aligned}
$$

Table 3. Performance of unit root test of L(fiscalrevenue/GDP), L(publicexpenditure /GDP)

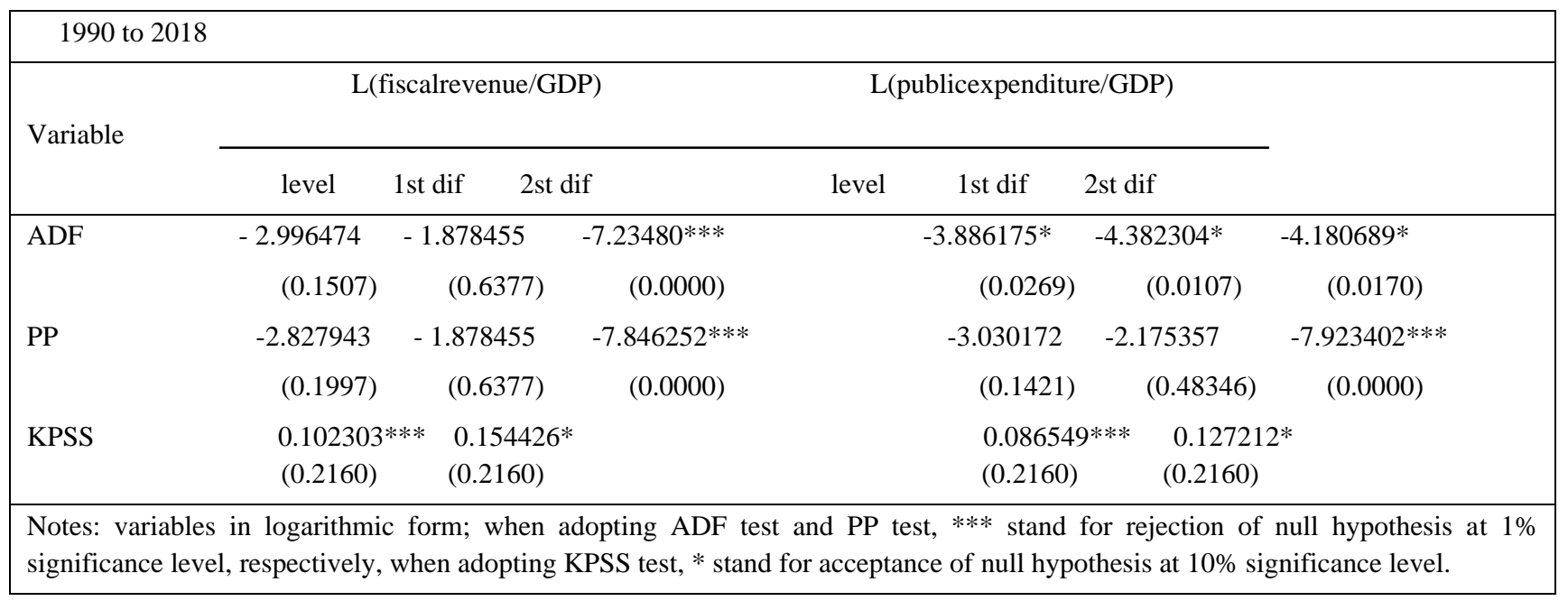

Source: Analyzed by us

According to the principle of boundary test, the null hypothesis is that there does not exist co-integration relationship among variables. Referring to Keho (2010b), we utilize ADRL boundary test model for Pesaran co-integration verification and investigate the cointegration approach among those variables for China over a time period ranging from 1990 to 2018. In Table 4, we show that under a significant level of 5\%, when L(fiscalrevenue/GDP) is dependent variable, it is impossible to reject the null hypothesis that there does not exist co-integration, and under a significant level of 5\%, when L(publicexpenditure/GDP) is dependent variable, the F-statistic of joint verification is 8.378412 higher than the upper critical value of 4.16, indicating a significant rejection of null hypothesis, depicting that there is a unidirectional co-integration casuality between L(fiscalrevenue/GDP) and L(publicexpenditure/GDP). 
Table 4. ARDL boundary test

\begin{tabular}{|c|c|c|c|c|c|c|c|}
\hline \multicolumn{8}{|c|}{1990 to 2018} \\
\hline \multicolumn{2}{|c|}{ Dependent Variable } & \multicolumn{5}{|c|}{ F- Statistics value } & co-integration \\
\hline Case1 & DL (publicexpenditure/GDP) & \multicolumn{5}{|c|}{$8.378412 * *$} & Yes \\
\hline Case2 & DL (fiscalrevenue/GDP) & & & 0.721 & & & No \\
\hline \multicolumn{8}{|c|}{$\begin{array}{l}1 \\
\text { Boundary values at different levels }\end{array}$} \\
\hline \multicolumn{2}{|r|}{ Significant level } & \multicolumn{2}{|c|}{$1 \%$} & \multicolumn{2}{|c|}{$5 \%$} & \multicolumn{2}{|c|}{$10 \%$} \\
\hline \multicolumn{2}{|c|}{$\begin{array}{l}\text { Order of } \\
\text { variables }\end{array}$} & LCB & UCB & LCB & $\mathrm{UCB}$ & LCB & UCB \\
\hline \multicolumn{2}{|c|}{$\begin{array}{l}\text { Case FII: } \\
\text { Limited intercept terms; no trend. }\end{array}$} & 4.94 & 5.58 & 3.62 & 4.16 & 3.02 & 3.51 \\
\hline \multicolumn{2}{|c|}{$\begin{array}{l}\text { Case FIII: } \\
\text { Limited intercept terms; no trend. }\end{array}$} & 6.84 & 7.84 & 4.94 & 5.73 & 4.04 & 4.78 \\
\hline
\end{tabular}

Source: Analyzed by us

Proposition 1: At 5\% significant level, F(L(fiscalrevenue/GDP)/

$\mathrm{L}($ publicexpenditure/GDP $) \times \mathrm{L}$ (fiscalrevenue/GDP) is 0.72125 , which is

lower than the lower critical value of 3.62 , but $\mathrm{F}$ (L/publicexpenditure

$/ G D P) / L(f i s c a l r e v e n u e / G D P)) \times \mathrm{L}$ (publicexpenditure/GDP) is 8.378412, which is higher than the upper critical value of 4.16, indicating that only one-way positive casuality exists between L(publicexpenditure/GDP) (dependent variable) and L(fiscalrevenue/GDP) ( independent variable).

Proposition 1 shows that when Johansen's co-integration relationship does not exist between L(fiscalrevenue/GDP) and L(publicexpenditure/GDP), the ARDL boundary test denotes that at a significant level of 5\%, co-integration exists only in the regression equation with $\mathrm{L}$ (publicexpenditure/GDP) as the interpreted variable. That is to say, when we utilize ADRL boundary test for Pesaran co-integration verification,checking the co-integration approach among those variables for China over a time period ranging from 1990 to 2018, we find that L(fiscalrevenue/GDP) affect L(publicexpenditure/GDP), but the causality does not hold in reverse. On the other hand, when $\mathrm{L}$ (publicexpenditure/GDP) is a dependent variable, it has one-way co-integration with L(fiscalrevenue/GDP), the independent variable.

\subsection{Long-Term Interrelation Analysis}

As can be seen from equation (4), the long-term correlation coefficient between

$\mathrm{L}\left(\right.$ publicexpenditure/GDP) and $\mathrm{L}\left(\right.$ fiscalrevenue/GDP) is $-\frac{\theta_{2}}{\theta_{1}}$;

$$
\begin{aligned}
\Delta \mathrm{L}(\text { publicexpenditure/GDP })_{\mathrm{t}} & =\alpha_{1}+\sum_{i=1}^{p} \beta_{1 i} \Delta \mathrm{L}(\text { publicexpenditure/GDP })_{t-i} \\
& +\sum_{i=0}^{q} \gamma_{1 i} \Delta \mathrm{L}(\text { fiscalrevenue/GDP })_{t-i} \\
& +\theta_{1} \mathrm{~L}(\text { publicexpenditure/GDP })_{t-1} \\
& +\theta_{2} \mathrm{~L}(\text { fiscalrevenue/GDP })_{t-1}+\varepsilon_{1 t}
\end{aligned}
$$

Moreover, due to the lack of Johansen cointegration relationship among those variables, we estimate the long-term relevance by using OLS and ARDL boundary test (see Pesaran et al,2001). During 1990-2018, when $\mathrm{L}$ (publicexpenditure/GDP) is the dependent variable, L(fiscalrevenue/GDP) is the independent variable, the result is listed in Table 5 denoting that L(fiscalrevenue/GDP) and L(public expenditure/GDP) have a long-term positive relevance at the $1 \%$ significant level under both OLS and ARDL boundary test. In other words, from a long-term perspective, the increment of L(fiscalrevenue/GDP) leads to the increase of $\mathrm{L}$ (publicexpenditure/GDP), but an increment in L(publicexpenditure/GDP) does not necessarily lead to an increase in L(fiscalrevenue/GDP). On the other hand, L(fiscalrevenue/GDP) and L(publicexpenditure/GDP) display a one-way long-term positive relevance. 
Table 5. Estimation of long-term relationship

\begin{tabular}{|l|c|c|}
\hline 1990 to 2018 & OLS & ARDL \\
\hline \multirow{2}{*}{ Dependent Variable } & Independent Variable & Independent Variable \\
\hline L(publicexpenditure/GDP) & L(fiscalrevenue/GDP) & L(fiscalrevenue/GDP) \\
\cline { 2 - 3 } & $1.007602 * * *$ & $0.545713 * * *$ \\
& $(27.62418)$ & $(2.879594)$
\end{tabular}

1. OLS is estimated by the least square method and ARDL long-term relationship coefficient is estimated by bounds test equation.

2.variables in logarithmic form; *,*, *** stand for at $1 \%, 5 \%$ and $10 \%$ significance level; the number in brackets is the t-statistic of the estimated parameter

Source: Analyzed by us

\subsection{Stability Diagnostics}

Next, in table 6, we adopt Chow test to check whether there exist structural change in the China's taxation system reform in 1994. From table 6, we display that the p-value of the F-statistic at that time 1994 taxation reform is 0.4759 , indicating that there has no structural change during the sample period (1990-2018). Furthermore, we adopt Ramsey reset to check whether the model omits some relevant variables or is suitable. In Table 6, we show that the p-values of $F$ statistic and likelihood statistic are 0.2369 and 0.1881 , respectively, both of them are greater than the significance level of $5 \%$. Therefore, it is hard to reject the null hypothesis that the model does not omit important variables, denoting that the model does not omit some relevant variables. Then we utilize CUSUM (cumulative sum) and CUSUM-sq (CUSUM squared) tests to inspect the stability and constancy for OLS result. Figure 1 displays the CUSUM curve is within two critical straight lines and does not exceed the range.It is proved that the parameters of the model are stable. Similarly, Figure 2 shows the CUSUM square curve is within two critical straight lines and does not exceed the range which proves the parameters of the model are stable.

\section{Fluctuation Diagnosis}

\subsection{Unexpected Impulse Analysis}

Next, we discuss the interaction between L(fiscalrevenue/GDP),

L(publicexpenditure/GDP), respectively. As mentioned above, due to the order of integration among those variables are not the same order in the model. Thus, we utilize structural VAR (Vector Autoregressive) for accurancy and treat all variables as endogenous variables to overcome the doubts about the identification of endogenous and exogenous variables (Sims,1980). However, owing to Sims (1980) method has a weakness of variable ranking, that is, the different order of variables entering VAR model will lead to different results for impulse response analysis or prediction error variance decomposition. This is called the ranking problem in the traditional literature. However the general prediction error variance decomposition method (see Koop, Pesaran, Potter, 1996) and the general impulse response analysis ( see Pesaran and Shin, 1998) can solve the above ranking problem. That is to say, when an impulse is applied to the error term of each variable in each equation, the effect of the shock on structural VAR can be observed over a period of time. Then, if the VAR system is stable, the shock will gradually disappear over time. 
Table 6. Stability Diagnostics

\begin{tabular}{|c|c|c|c|}
\hline 1990 to 2018 & & & \\
\hline Method 1: Chow Br & eakpoint Test 1 & & \\
\hline Null Hypothesis:No & breaks at speci & breakpoints & \\
\hline Varying regressors: & All equation va & & \\
\hline F-Statistic & 0.764977 & Prob. F(2,25) & 0.4759 \\
\hline Log likehood ratio & 1.722561 & Prob.Chi-Square(2) & 0.4226 \\
\hline Wald Statistic & 1.529955 & Prob.Chi-Square(2) & 0.4653 \\
\hline od 2: R & SET & & \\
\hline & value & Proba & bility \\
\hline F-Statistic & 1.526434 & $(2,25)$ & \\
\hline Likehood ratio & 3.341236 & 0.188 & \\
\hline
\end{tabular}

Source: Analyzed by us

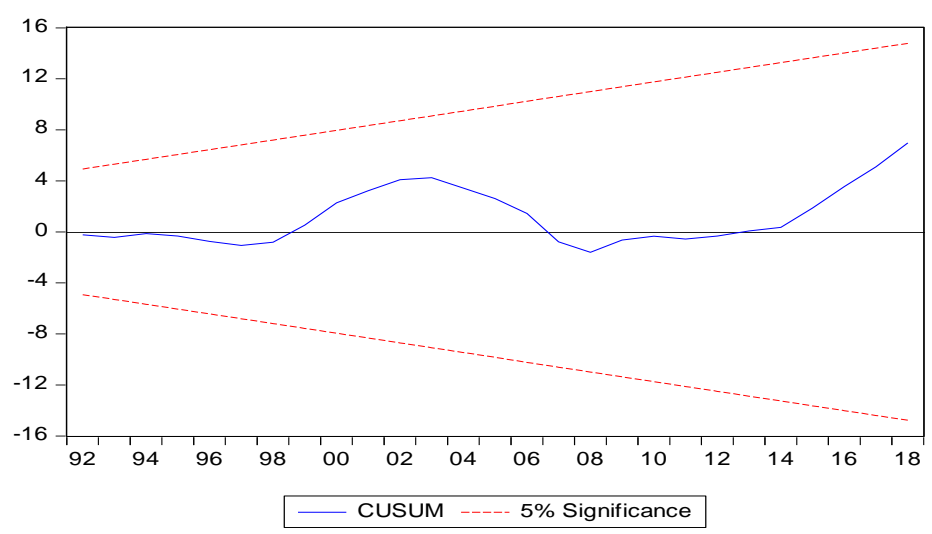

Figure 1. CUSUM test result

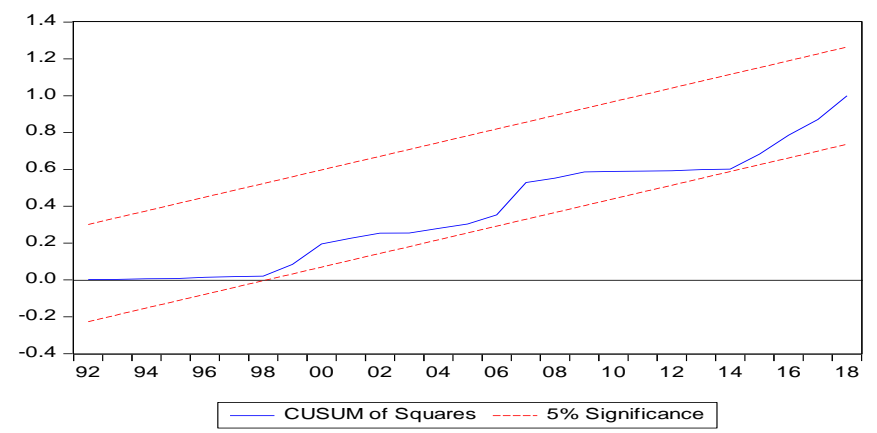

Figure 2. CUSUM of Square Test

As mentioned above, L(publicexpenditure/GDP) is dependent variable, $\mathrm{L}$ (fiscalrevenue/GDP) is independent variable, In other words, from a long-term perspective, the increase of L(fiscalrevenue/GDP) leads to the increase of L(publicexpenditure/GDP), but an increase in L(publicexpenditure/GDP) does not necessarily lead to an increase in L(fiscalrevenue/GDP). L(fiscalrevenue/GDP) and L(publicexpenditure/GDP) present one-way and long-term positive relevance.

Next, we further observe the one unit standard deviation impact of L(fiscalrevenue) and LGDP on L(publicexpenditure), respectively. From Figure 3, we find that the impact of $\mathrm{L}$ (fiscalrevenue) on $\mathrm{L}$ (publicexpenditure) is unidirectional and positive, but the impact of LGDP on L(publicexpenditure) is negative. This reveals that China's fiscal policy in recent years is inclined to adopt "balanced and cyclical fiscal policy" rather than the fiscal instrument of "current balance of payments policy". 
Response to Cholesky One S.D. (d.f. adjusted) Innovations Response of LNPUBLICEXPENDITURE to Innovations

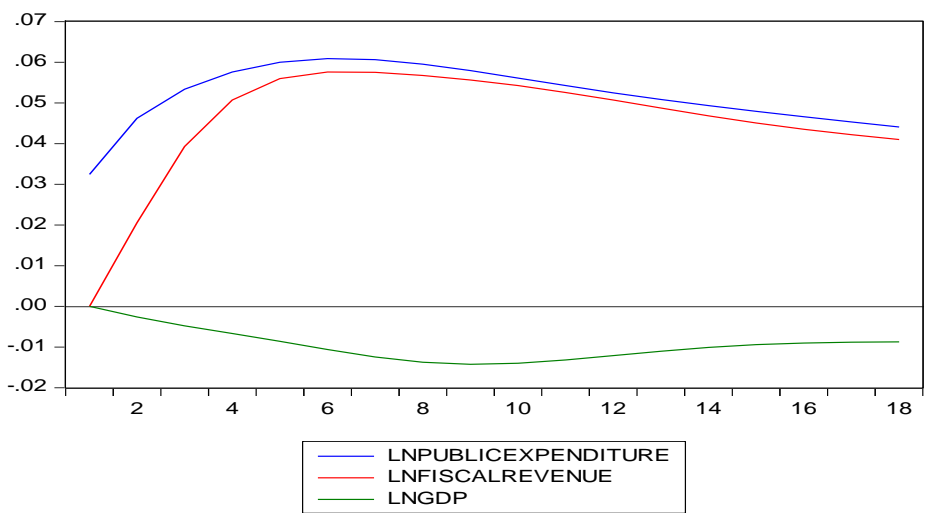

Figure 3. Impulse of L(fiscalrevenue) and LGDP on L(publicexpenditure)

Proposition 2: When we observe the prediction error variation of L(fiscalrevenue) and L(GDP) on $\mathrm{L}$ (publicexpenditure). As can be seen from Table 7. Initially, it denotes that the unexpected impact variation of L(fiscalrevenue) and LGDP on L(public expenditure) is tiny. However, when we estimate it in the next 18 periods, LGDP can only explain $2.02 \%$ of L(publicexpenditure) error variation, while L(fiscalrevenue) can explain $44.25 \%$ of $\mathrm{L}$ (publicexpenditure) error variation, revealing that $\mathrm{L}$ (fiscalrevenue) and $\mathrm{L}$ (publicexpenditure) are more relevant than LGDP and L(public expenditure).

Table 7. Variance Decomposition of L(publicexpenditure)

\begin{tabular}{|ccccc|}
\hline \multicolumn{1}{|l}{ Period } & Std Error & L(publicexpenditure) & $\underline{\text { L(fiscalrevenue) }}$ & $\underline{\text { L(gdp) }}$ \\
2 & 0.032459 & 100.00 & 0.00 & 0.00 \\
3 & 0.060148 & 88.15 & 11.65 & 0.18 \\
4 & 0.089612 & 75.16 & 24.46 & 0.37 \\
5 & 0.118181 & 66.98 & 32.48 & 0.52 \\
6 & 0.144138 & 62.36 & 36.92 & 0.71 \\
7 & 0.167084 & 59.70 & 39.36 & 0.93 \\
8 & 0.187239 & 58.03 & 40.77 & 1.18 \\
9 & 0.204971 & 56.86 & 41.69 & 1.43 \\
10 & 0.234429 & 55.98 & 42.35 & 1.65 \\
11 & 0.246657 & 55.31 & 42.86 & 1.82 \\
12 & 0.257511 & 54.80 & 43.26 & 1.93 \\
13 & 0.267196 & 54.43 & 43.56 & 1.99 \\
14 & 0.275903 & 54.18 & 43.79 & 2.02 \\
15 & 0.283796 & 54.01 & 43.95 & 2.03 \\
16 & 0.291013 & 53.90 & 44.06 & 2.02 \\
17 & 0.297661 & 53.83 & 44.14 & 2.02 \\
18 & 0.303819 & 53.77 & 44.20 & 2.02 \\
\hline
\end{tabular}

Source: Analyzed by us

\subsection{Auto Regressive Conditional Heteroskedasitcity (ARCH) Analysis}

Next we detect whether there exists clustering effect of residual square variation under the impact of fiscal revenue on public expenditure (Engle, 1987) and check the fluctuation degree of the change of fiscal revenue on public expenditure.Regarding EGARCH can better capture the volatility of time series and the risk of variance than GARCH(Neslon, 1991). In this paper,the main findings are as follows:

(1) In comparison with GARCH and EGARCH and PGARCH models, we show that L(fiscalrevenue withgdp) has a positive correlation with

$\mathrm{L}$ (publicexpenditurewithgdp), and the $\mathrm{p}$ value is significant under 0.05 , depicting $\mathrm{p}=0.0000<0.05$. 
(2) Owing to $\mathrm{c}(5)=-0.408807<0$ in EGARCH model,and also c $(5)=-0.955462<0$ in PGARCH model, denoting that the conditional variance has asymmetric response with different impact degrees of "good" news and "bad" news.

(3) GARCH model denotes that the square term of the residual sequence is $2.235301, p=0.0389<0.05 p$ which is significant under 0.05 . It shows that there exists a certain degree of self correlation between the square terms of the residual sequence, On the other hand, there exists a auto regressive conditional

heteroskedasitcity(ARCH) under the time series.

Table 8. ARCH Test Result

\begin{tabular}{|c|c|c|}
\hline \multicolumn{3}{|l|}{$1990-2018$} \\
\hline \multicolumn{3}{|l|}{ Model 1. GARCH } \\
\hline \multirow[t]{2}{*}{$\begin{array}{l}\text { Equation: } \\
\text { GARCH }=\mathrm{c}(3)+\mathrm{c}(4) * \operatorname{RESID}(-1)^{\wedge} 2+\mathrm{c}(5) * \operatorname{GARCH}(-1)\end{array}$} & $\begin{array}{l}\text { Lfiscalrevenue } \\
\text { withfdp }\end{array}$ & $\begin{array}{l}\text { Variance } \\
\text { Euqation }\end{array}$ \\
\hline & $\begin{array}{l}1.030625 \\
(0.0000) * * *\end{array}$ & $\begin{array}{l}\text { RESID }(-1)^{\wedge} 2=2 \text {. } \\
235301 \\
(0.0389)^{*}\end{array}$ \\
\hline \multicolumn{3}{|l|}{ Model 2. EGARCH } \\
\hline \multirow{2}{*}{$\begin{array}{l}\text { Equation: } \\
\text { LOG(GARCH)=c(3)+c(4)*ABS(RESID(-1)/@SQRT(GARCH(-1)))+c(5)*RESID(-1)@ SQR } \\
\text { T(GARCH(-1))+c(6)*LOG(GARCH(-1)) }\end{array}$} & $\begin{array}{l}\text { Lfiscalrevenuew } \\
\text { ithfdp }\end{array}$ & $\begin{array}{l}\text { Variance } \\
\text { Euqation } \\
\end{array}$ \\
\hline & $\begin{array}{l}1.044266 \\
(0.0000) * * *\end{array}$ & $\begin{array}{l}c(5)=-0.408807 \\
<0 \\
(0.0374)^{*}\end{array}$ \\
\hline \multicolumn{3}{|l|}{ Model 3. PGARCH } \\
\hline \multirow{2}{*}{$\begin{array}{l}\text { Equation: } \\
@ \text { SQRT(GARCH })^{\wedge} \mathrm{c}(7)=\mathrm{c}(4)^{*}\left(\operatorname{ABS}(\operatorname{RESID}(-1))-\mathrm{c}(5) * \operatorname{RESID}(-1)^{\wedge} \mathrm{c}(7)+\mathrm{c}(6)^{*} @ \operatorname{SQRT}(\mathrm{GAR}\right. \\
\mathrm{CH}(-1)^{\wedge} \mathrm{c}(7)\end{array}$} & $\begin{array}{l}\text { Lfiscalrevenuew } \\
\text { ithfdp }\end{array}$ & $\begin{array}{l}\text { Variance } \\
\text { Euqation }\end{array}$ \\
\hline & $\begin{array}{l}0.998436 \\
(0.0000)^{* * *}\end{array}$ & $\begin{array}{l}c(5)=-0.955462 \\
<0\end{array}$ \\
\hline
\end{tabular}

Source: Analyzed by us

\section{Conclusion and Discussion}

According to the database of the National Bureau of statistics of China, China's fiscal deficit accounted for $1.78 \%$ of GDP in 2014, which is in accordance with the provisions of the Maastrick treaty and the stability and growth pact that came into force in 1993 and 1997and ask for the annual fiscal deficit of each country shall not exceed 3\% of GDP in deficit. In this paper, we show the proportion of deficit is reasonable. However, it increased to $3.44 \%$ in $2015,3.8 \%$ in $2016,3.71 \%$ in 2017 and $4.17 \%$ in 2018 . Obviously, it can be seen that in recent years, the proportion of fiscal deficit to GDP has been increasing year after year, which has exceeded the above warning line of 3\% of GDP in deficit.

According to the analysis of our empirical analyses, we denote that China's fiscal revenue has a one-way and positive impact on public expenditure, but public expenditure does not appear one-way positive/negative impact on fiscal revenue. On the other hand, if the fiscal revenue has a positive one-way impact on expenditure (tax spend hypothesis), it means that increasing revenue will lead to the increment of public expenditure, but reducing expenditure will not lead to the reduction of fiscal revenue.

Generally speaking, Fiscal Illusion makes people more likely to ask the government to increase fiscal expenditure in order to provide more public services, rather than to express the demand to reduce public expenditure. In recent years, with the improvement of modernization and living standards, China, like other countries, has increased the proportion of public expenditure year by year. This paper finds that tax increase is relatively easy to lead to the increase of public expenditure, and the improvement of fiscal deficit must start from the reduction of expenditure. Therefore, it is suggested to optimize the structure of fiscal expenditure, including the proportion of productive expenditure and non productive expenditure, the proportion of purchasing expenditure and transfer expenditure, in order to improve the overall efficiency of public expenditure.

In sum, in order to attract capital, local tax competition is prone to provide too much local public wealth. In addition, due to the less cooperation mechanism between local governments, it is easy to produce inefficient results in the total local government expenditure portfolio (see Bayindir Upmann,1998 and Keen \& Marchand,1997). This part will be further studied and analyzed in the future.

\section{References}

Barro, R. J. (1979). On the determination of the Public Debt. Journal of Political Economy, 87, 940-971. 
Baumöhl, E., \& Lyócsa, Š. (2009). Stationarity of time series and the problem of spurious regression. MPRA Paper, 27926, 1-16. https://doi.org/10.2139/ssrn.1480682

Brock, W., Davis, D., Jose, S., \& Blake, L. (1996). A Test for Independence Based on the Correlation Dimension. Econometric Review, 15(3), 197-235. https://doi.org/10.1080/07474939608800353

Buchanan, J. M., \& Wagner, R. E. (1977). Democracy in Deficit : the Political Legacy of Lord Keynes. New York : Academic Press.

Cameron, D. R. (1978). The Expansion of the Public Economy: A Comparative Analysis. American Political Science Review, 72(4), 1243-1261. https://doi.org/10.2307/1954537

Christian, G. (2012). Explaining the (non-) causality between energy and economic growth in the U.S.-A multivariate sectoral analysis. Energy Economics, 34(2), 489-499. https://doi.org/10.1016/j.eneco.2011.12.002

Dickey, D. A., \& Fuller, W. A. (1979). Distribution of Estimators for Time Series Regressions with a Unit Root. Journal of the American Statistical Association, 74, 427-431. https://doi.org/10.1080/01621459.1979.10482531

Enders, W. (2010). Applied Econometric Time Series. New York: John Wiley.

Engle, R. F., \& Granger, C. W. J. (1987). Co-integration and Error-correction: Representaion, Estimation and Testing. Econometrica, 55, 251-276.

Friedman, M. (1978). The Limitations of Tax Limitation. Policy Review (Summer), 7-14.

Gramlich, E. M., \& Harvey, G. (1973). State and Local Fiscal Behavior and Federal Grant Policy. Brookings Papers on Economic Activity, 1, 15-58. https://doi.org/10.2307/2534084

Granger, C. W., \& Newbold, P. (1974). Spurious Regressions in Econometrics. Journal of Econometrics, 2(2), 111-120. https://doi.org/10.1016/0304-4076(74)90034-7

Hewitt, D. (1986). Fiscal illusion from grants and the level of state and federal expenditures. National Tax Journal, 39, 471-484.

James, R., Hines, J., \& Richard, H. T. (1995). Anomalies the Flypaper Effect. Journal of Economic Perspectives, 9(4), 217-226. https://doi.org/10.1257/jep.9.4.217

Johansen, S., \& Juselius, K. (1990). Maximum likelihood estimation and inference on cointegration with application to the demand for money. Oxford Bulletin Economics and Statistics, 95, 615-628. https://doi.org/10.1111/j.1468-0084.1990.mp52002003.x

Keho, Y. (2010b). Budget Balance Through Revenue or Spending Adjustments? An Econometric Analysis of the Ivorian Budgetary Process. Journal of Economic and International Finance, 2(1), 1-11.

Koop, G., M. H., Pesaran, \& Potter, S. M. (1996). Impulse response analysis in nonlinear multivariate models. Journal of Econometrics, 74(1), 119-147.

Li, R. (2012). Intergovernmental Network Governance: Research on the relationship between vertical management departments and local governments. Shanghai: Fudan University Press: 139.

Meltzer, A. H., \& Scott, F. R. (1981). A Rational Theory of the Size of Government Source. The Journal of Political Economy, 89(5), 914-927. https://doi.org/10.1086/261013

Nelson, D. B. (1991). Conditional heteroscedasticity in asset returns: a new approach. Econometrica, 59, 347-370. https://doi.org/10.2307/2938260

Niskanen, W. A. (2006). Limiting Government: The Failure of 'Starve the Beast. Cato Journal, 26(3), 553-558.

Noriega, A. E., \& Ventosa-Santaularia, D. (2007). Spurious Regression and Trending Variables. In: Oxford Bulleting of Economics and Statistics, 69(3), 439-444. https://doi.org/10.1111/j.1468-0084.2007.00481.x

Obeng, S. (2015). A Causality Test of the Revenue-Expenditure Nexus in Ghana. ADRRI Journal of Arts and Social Sciences, 11(1), 1-19.

Peacock, A. T., \& Jack, W. (1979). Approaches to the Analysis of Government Expenditure Growth. Public Finance Review, 7, 3-23. https://doi.org/10.1177/109114217900700101

Pesaran, H. H., \& Shin, Y. (1998). Generalized Impulse Response Analysis in Linear Multivariate Models. Economics Letters, 58, 17-29. https://doi.org/10.1016/S0165-1765(97)00214-0

Pesaran, H. M., \& Shin, Y. (1999). Autoregressive distributed lag modelling approach to coin-tegration analysis. In Econometrics and economic theory in the 20th Century: The Ragnar Frisch centennial symposium, ed. S. Storm. Cambridge: Cambridge University Press. 
Pesaran, H. M., \& Shin, Y., \& Smith, R. J. (2001). Bounds Testing Approaches to the Analysis of Level Relationships. Journal of Applied Econometrics, 16, 289-326. https://doi.org/10.1002/jae.616

Sims, C. A. (1980). Macroeconomics and Reality. Econometrica, 48, 1-48. https://doi.org/10.2307/1912017

Wagner, R. E. (1976). Revenue Structure, Fiscal Illusion, and Budgetary Choice. Public Choice, 25 (Spring), 30-61. https://doi.org/10.1007/BF01726330

\section{Copyrights}

Copyright for this article is retained by the author(s), with first publication rights granted to the journal.

This is an open-access article distributed under the terms and conditions of the Creative Commons Attribution license which permits unrestricted use, distribution, and reproduction in any medium, provided the original work is properly cited. 